\title{
Small Ubiquitin-Related Modifier 1
}

National Cancer Institute

\section{Source}

National Cancer Institute. Small Ubiquitin-Related Modifier 1. NCI Thesaurus. Code C106291.

Small ubiquitin-related modifier 1 (101 aa, $12 \mathrm{kDa}$ ) is encoded by the human SUMO1 gene. This protein plays a role in post-translational protein modification. 